\title{
Evaluation of endothelial function and platelet activation in dyslipidemic children
}

\section{Dislipidemik çocuklarda endotelyal fonksiyon ve trombosit aktivasyonunun değerlendirilmesi}

\author{
Sema KALKAN UÇAR ${ }^{1}$, Yasemin DELEN AKÇAY ${ }^{2}$, Turan KOLOĞLU ${ }^{2}$, Ertürk LEVENT ${ }^{1}$, \\ Eser Yıldırım SÖZMEN², Mahmut ÇOKER ${ }^{1}$
}

${ }^{1}$ Ege Üniversitesi Tip Fakültesi, Çocuk Sağlı̆̆ı ve Hastalıkları Anabilim Dalı, İzmir

${ }^{2}$ Ege Üniversitesi Tip Fakültesi, Tibbi Biyokimya Anabilim Dalı, İzmir

\begin{abstract}
Objective: The aim of this study was to determine the parameters of endothelial function and platelet activation in children with familial hypercholesterolemia by measuring plasma homocysteine, asymmetrical dimethyl arginine (ADMA), nitrotyrosine and P-selectin levels.

Methods: Thirty-five heterozygous familial hypercholesterolemic patients on statin therapy, 10 homozygous familial hypercholesterolemic patients treated by LDL apheresis and lipid-lowering drugs, and 25 healthy children, all aged between 2 to 16 years were enrolled in this study. Echocardiography was performed and intima-media thickness (IMT), and endotheliumdependent vasodilation parameters were evaluated. LDL apheresis was performed by adsorption method using double-membrane filtration technique. Plasma nitrotyrosine, homocysteine, P-selectin and ADMA levels were determined with an enzyme-linked immunosorbent assay (ELISA) using a commercial kit.

Results: Plasma homocysteine ( $p=0.000)$, ADMA ( $p=0.005)$, nitrotyrosine $(p=0.808)$, $p$-selectin $(\mathrm{p}=0.466)$ levels were lowest in the LDL apheresis group. A positive correlation was detected between homocysteine and intima/media thickness $(\mathrm{r}=0.334, \mathrm{p}=0.043)$. Showed that LDL apheresis therapy might decrease plasma levels of homocysteine, ADMA, and nitrotyrosine, and might eventually play an important role in the improvement of endothelial dysfunction and platelet activity.

Conclusion: Our data showed that at post-LDL apheresis status the homozygous hyperlipidemic children have lower levels of homocysteine, ADMA, and nitrotyrosine, compared with the heterozygous hyperlipidemic children.
\end{abstract}

Key words: Children, homozygous/heterozygous familial hypercholesterolemia, homocysteine, asymmetrical dimethyl arginin (ADMA), nitrotyrosine

$\ddot{\mathbf{O Z Z}}$

Amaç: Bu çalışmada ailesel hiperlipidemi tanılı çocuklarda plazma homosistein, asimetrik dimetil arjinin, nitrotirozin ve p-selektin üzerinden endoteliyal fonksiyon ve trombosit aktivasyonunu plazma homosistein, asimetrik dimetil arjinin, nitrotirozin ve p-selektin aracılığı ile değerlendirmek amaçlandı.

Yöntemler: Çalışmaya 2-16 yaş arası, statin kullanan 35 ailesel heterozigot hiperlipidemik hasta, LDL-ferez uygulanan 10 homozigot hiperlipidemik hasta ve 25 sağlıklı çocuk katılmıştır. "İntima-media" kalınlığı, endotelium bağımlı vazodilatasyon göstergeleri ekokardiyografi aracılığı ile değerlendirilmiştir. LDL-aferez işleminde absorpsiyon yöntemine dayalı çift membran tekniği kullanılmıştır. Plazma nitrotirozin, homosistein, asimetrik dimetil arjinin, ve p-selektin düzeyleri ELISA yöntemi ile bakılmıștır.

Bulgular: Çalışmamızda, plazma homosistein düzeyi $(p=0,000)$, ADMA ( $p=0.005)$, nitrotirozin $(p=0.808)$, p-selektin ( $p=0.466)$ LDL-ferez olan uygulanan grupta en düşük bulunmuştur. Plazma homosistein ve "intima/media" kalınlığı arasında $(\mathrm{r}=0.334, \mathrm{p}=0.043)$ pozitif korelasyon saptanmıştır. Çalışmamızda, LDL-ferez olan grupta plazma homosistein, ADMA ve nitrotirozin düzeyleri anlamlı düşük bulunmuş olup, endotaliyal disfonksiyon ve platelet aktivasyonun iyileştirilmesinde önemli bir role sahip olabileceği düşünülmüştür.

Sonuȩ: Bu çalışmada, homozigot hiperlipidemi grubunun LDL-ferez sonrası homosistein, ADMA, ve nitrotirozin seviyeleri heterozigot hiperlipidemik çocuklara göre anlamlı oranda düşïk saptanmıştır.

Anahtar kelimeler: Çocuklar, ailesel homozigot/heterozigot hiperlipidemi, homosistein, asimetrik dimetil arjinin (ADMA), nitrotirozin
Alındığı tarih: 08.01.2016

Kabul tarihi: 03.02.2016

Yazışma adresi: Doç. Dr. Sema Kalkan Uçar, Ege Üniversitesi, Çocuk Sağlığı ve Hastalıkları, Bornova-35100-İzmir

e-mail: semakalkan@hotmail.com 


\section{INTRODUCTION}

Familial hypercholesterolemia (FH) is an autosomal dominant disorder characterized by elevated low-density lipoprotein cholesterol levels caused by defects in the gene encoding LDL receptor ${ }^{(1)}$. LDLapheresis in combination with lipid-lowering drugs is the most effective treatment, which may reduce LDL-cholesterol levels by more than $70 \%$ in homozygous FH patients; however heterozygous patients are treated with lipid-lowering drugs ${ }^{(1)}$. Several studies have shown that high levels of serum lipids may cause endothelial dysfunction which is recognized as the first step of the arterial wall modifications that would initiate and support the development of an atherosclerotic lesion ${ }^{(2-4)}$.

Recently, a wide variety of cytokines and soluble adhesion molecules such as selectins, intercellular adhesion molecule-1, vascular cell adhesion molecule- 1 have been associated with atherosclerotic disease. The inflammatory response correlated with hypercholesterolemia may involve intrinsic cells of the artery wall, and circulating cells, such as platelets, as well. The contribution of platelets to the process of atherosclerosis is correlated with the secretion of different biologically active substances ${ }^{(5)}$.

Hyperhomocysteinemia tends to appear as a laboratory finding in cases with peripheral, cerebral and coronary artery diseases and venous thrombosis, as well. In several studies, hyperhomocysteinemia was shown as an independent risk factor of vascular diseases. Hyperhomocysteinemia may lead to endothelial damage, and related diseases. Vascular toxicity of homocysteine may occur due to various factors ${ }^{(6,7)}$.

Activating platelets and increasing serum asymmetrical dimethylarginine (ADMA) levels are among the mechanisms of homocysteine in causing or accelerating atherosclerosis. ADMA, is considered as one of the risk factors for atherosclerosis, and acts as an inhibitor of nitric oxide synthesis, therefore it can lead to vasospasm and endothelial dysfunction ${ }^{(8)}$.

Nitrotyrosine is a commonly known marker for peroxynitrite synthesis detected in both normal and diseased tissues. Nitrotyrosine antibodies unergo nitration in human atherosclerosis, myocardial ischemia, septic and distressed lung, inflammatory bowel disease, and amyotrophic lateral sclerosis ${ }^{(9)}$.
P-selectin, is an indicator reflecting platelet activation and endothelial cell functions in conditions like hyperlipidemia and endothelial damage.

Although, recent studies have been conducted on the effects of LDL apheresis, the effects of this method on the parameters in relation with endothelial function and platelet activation such as homocysteine, ADMA, nitrotyrosine and p-selectin have not been investigated yet.

The aim of the present study was to investigate the endothelial variables (homocysteine, ADMA, nitrotyrosine and p-selectin) in homozygous FH patients at post-apheresis status as compared with age- and gender-matched heterozygous FH patients who are on lipid-lowering drug therapy and healthy subjects.

\section{MATERIALS and METHODS}

Thirty-five consecutive patients with heterozygous FH (Group 1) and ten with homozygous FH undergoing LDL apheresis (Group 2), aged between 2 to 16 years, were enrolled in this study. Healthy subjects $(n=25$; age range 2-16) served as healthy controls (Group 3).

All patients with homozygous FH were initially treated with concomitant diet (saturated fat below $7-10 \%$ of energy intake, cholesterol below $200 \mathrm{mg} /$ day) and oral drug therapy (HMG-CoA reductase inhibitors, atorvastatin 20-40 mg/day for patients younger than 6 years; and 40-80 mg/day for patients older than 6 years plus ezetimib at a dose of $10 \mathrm{mg} /$ day). Low-dose anticoagulant therapy (salicylic acid at cardiologic doses) was administrated during ongoing surveillance of cardiovascular disease. According to the hematological parameters and electrolyte levels, oral iron or calcium was supplemented to protect the patients from iron deficiency anemia and hypocalcaemia. All homozygous FH patients underwent LDL-apheresis on two or three-weekly basis. Heterozygous patients were on diet (saturated fat below 7-10\% of energy intake, cholesterol below 200 $\mathrm{mg}$ /day) and oral drug therapy (HMG-CoA reductase inhibitors, atorvastatin 20-40 mg/day).

Physical examinations of all the participants were performed in Pediatric Metabolic Diseases Outpatient Unit (2014). Demographic data such as age, gender, family history of dyslipidemia were recorded in patient files. Echocardiographic evaluations were perfor- 
med. Carotid artery intima-media thickness (CIMT)) was measured by the same pediatric cardiologist during the outpatient visits. CIMT was assessed by an ultrasound device (GE Vingmed, Vivid 7.0, Ultrasound AS, Horten, Norway) equipped with a linear $12 \mathrm{Mhz}$ high-resolution probe.

LDL apheresis was performed by adsorption method by using double membrane filtration technique. Plasma was obtained by centrifugation using a blood cell separator (ExcelPro; Dideco, Mirandola, Italy). After separation of plasma, the adsorption was controlled by adsorption-desorption equipment (ADA; Medicap, Ulrichstein, Germany, and Lipocollect 200 (Medicollect, Rimbach, Germany)] ${ }^{(10)}$.

Following an overnight fast, blood samples from patients with heterozygous familial hypercholesterolemia and control group were collected in both Heparin/EDTA containing tubes and anticoagulantfree tubes. Plasma and serum were separated immediately. The samples from homozygous FH patients undergoing LDL-apheresis were collected two hours after LDL-apheresis procedure.

Plasma cholesterol and triglyceride levels were measured according to standardized procedures. Total plasma lipid levels were quantified photometrically (11). Nitrotyrosine (3-NT) (Hycult biotechnology, cat no. HK501, The Netherlands), ADMA (Immune Diagnostic, cat no. K 7828-091012, Bensheim), homocysteine (IBL, cat no AX51301, Hamburg, German), p-selectin (Bender Medsystem, Human sP-selectin Platinum ELISA cat. No: BMS205, Vienna, Austria) concentrations were investigated with an enzyme-linked immunosorbent assay using a commercial kit.

The study protocol was approved by The Regional Committee of Medical Ethics and written informed consent was obtained from all subjects or parents (10-TIP-014, 2014).

Statistical Package for Social Studies (SPSS), version 13.0 was used in all statistical analyses. Student's $t$ test was used to compare the mean values of the study groups. Within group comparisons were performed by Kruskal-Wallis test. Relationships among all of the variables were evaluated by Pearson's Correlation test. All parametric results were expressed as mean \pm standard deviation (SD). P values less than 0.05 were accepted as statistically significant.

\section{RESULTS}

Data concerning demographic parameters have been presented in Table 1. There were no differences between ages, genders and BMIs of the compared groups. The differences between plasma lipid levels in heterozygous and homozygous groups after LDL-apheresis were similar. However, they were significantly higher when compared with the controls.

Table 1. Demographic characteristic of the patients.

\begin{tabular}{lccc}
\hline & $\begin{array}{c}\text { Group 1 } \\
\text { Mean } \pm \text { SD } \\
\mathbf{n = 3 5}\end{array}$ & $\begin{array}{c}\text { Group 2 } \\
\text { Mean } \pm \text { SD } \\
\mathbf{n = 1 0}\end{array}$ & $\begin{array}{c}\text { Group 3 } \\
\text { Mean } \pm \text { SD } \\
\mathbf{n = 2 5}\end{array}$ \\
\hline Age (years) & $9.8 \pm 4.8$ & $10.6 \pm 4.4$ & $10.1 \pm 4.1$ \\
Sex (male/female) & $18 / 17$ & $6 / 4$ & $13 / 12$ \\
BMI (kg/m ${ }^{2}$ ) & $16 \pm 2.5$ & $16 \pm 1.8$ & $17.05 \pm 2.1$ \\
Glucose (mg/dl) & $94 \pm 35$ & $80 \pm 12$ & $82 \pm 18$ \\
Total Cholesterol (mg/dl) & $284 \pm 128$ & $213 \pm 52$ & $190 \pm 43$ \\
HDL-Cholesterol mg/dl) & $52 \pm 15$ & $44 \pm 25$ & $47 \pm 14$ \\
LDL-Cholesterol (mg/dl) & $223 \pm 119$ & $154 \pm 131$ & $104 \pm 32 *$ \\
Trygliseride (mg/dl) & $136 \pm 90$ & $138 \pm 56$ & $87 \pm 57 *$ \\
& & & \\
\hline
\end{tabular}

$* p<0.05, * * p<0.01$

Group 1: Heterozygous Familial Hypercholesterolemic Patients

Group 2: Homozygous Familial Hypercholesterolemic Patients (After LDL-apheresis)

Group 3: Healthy Subjects (Control Group)

Plasma homocysteine $(\mathrm{p}=0.000)$, ADMA $(\mathrm{p}=0.005)$, nitrotyrosine $(\mathrm{p}=0.808), \quad \mathrm{p}$-selectin ( $\mathrm{p}=0.466$ ) levels were found to be significantly lower in the post-LDL apheresis homozygous FH group compared to heterozygous FH group (Table 2). However, homocysteine, ADMA and p-selectine values in homozygous FH group were similar to thethose of the control group.

Table 2. Comparison of the results of control, heterozygous FH and homozygous FH (LDL-apheresis) group.

\begin{tabular}{lccc}
\hline & $\begin{array}{c}\text { Group 1 } \\
\text { Mean } \pm \text { SD } \\
\mathbf{n = 3 5}\end{array}$ & $\begin{array}{c}\text { Group 2 } \\
\text { Mean } \pm \text { SD } \\
\mathbf{n = 1 0}\end{array}$ & $\begin{array}{c}\text { Group 3 } \\
\text { Mean } \pm \text { SD } \\
\mathbf{n = 2 5}\end{array}$ \\
\hline Homocysteine $(\mu \mathrm{mol} / \mathrm{L})$ & $11.6 \pm 4.6$ & $7.7 \pm 2.2^{* *}$ & $9.5 \pm 2.7$ \\
ADMA $(\mu \mathrm{mol} / \mathrm{L})$ & $1.4 \pm 0.16$ & $1.27 \pm 0.16^{*}$ & $1.38 \pm 0.21$ \\
P-Selectine $(\mathrm{ng} / \mathrm{ml})$ & $226 \pm 59$ & $218 \pm 39$ & $213 \pm 57$ \\
Nitrotyrosine $(\mathrm{nM})$ & $98 \pm 185$ & 1.8 & $24 \pm 30$ \\
& $\mathrm{n}=11$ & $\mathrm{n}=1$ & $\mathrm{n}=4$ \\
\hline
\end{tabular}

$* p<0.05, * * p<0.01$

Group 1: Heterozygous Familial Hypercholesterolemic Patients

Group 2: Homozygous Familial Hypercholesterolemic Patients (After

LDL-apheresis)

Group 3: Healthy Subjects (Control Group) 
A positive correlation was detected between homocysteine and intima/media thickness of all groups $(\mathrm{r}=0.334, \mathrm{p}=0.043)$.

With regard to plasma nitrotyrosine levels, higher values were observed in the heterozygous FH group compared to the control subjects and post-LDL apheresis homozygous FH (after LDL-apheresis status) group. Interestingly, the lowest values were found in the homozygous FH group after LDL-apheresis $(n=1)$. Here we need to emphasis that we could measure nitrotyrosine level only in one patient from the homozygous FH group after LDL-apheresis, while nitrotyrosine concentrations of the other LDL apheresis cases $(n=9)$ were measured below the detection range of the test method.

\section{DISCUSSION}

Currently, LDL-apheresis combined with potent statin therapy and other lipid-lowering drugs is the method of choice which can be able to reduce LDLcholesterol levels. In our previous studies we have reported a reduction of mean LDL-cholesterol at around $62.8 \pm 10.3 \%$ in homozygous familial hypercholesterolemia patients undergoing LDL-apheresis ${ }^{(10)}$. In recent years, in addition to benefits derived from reduction of LDL-cholesterol levels, the other possible mechanisms related to clinical improvement have been highlighted. The main approach is that LDL-apheresis might provide both structural and physiologic improvement in the vascular wall. For example, in patients with atherosclerosis, long-term LDL-apheresis slowed the progression of carotid intima-media thickness (CIMT). The suggestion is that beneficial effects in vascular function could be derived from apheresis- related effect on rheological parameters or by increasing (directly or indirectly) lipoprotein lipase activity ${ }^{(12)}$.

Based on this we hypothesized that at post-LDLapheresis status the homozygous and heterozygous patients will have similar lipid profile, which will provide a condition to compare other parameters demonstrating the endothelial functions.

Homocysteine is capable of damaging endothelium by producing free radicals, suppressing nitric oxide production and also preventing anticoagulation function of endothelium, which may lead to oxidati- on of low- density lipoprotein cholesterol, and development of atherosclerosis ${ }^{(13)}$. Reduction of homocysteine by LDL-apheresis is well documented (14), however there is no data in the current literature about status of homocysteine after LDL-apheresis in homozygous patients when compared with heterozygous patients. Our study demonstrated lower levels of homocysteine in post-LDL-apheresis homozygous FH group rather than heterozygous FH group. Take into account the shortness of LDL-aphersis effects is going to be an intended result.

It is evident that high levels of ADMA, which is an endogenous inhibitor of nitric oxide synthase, may be effective in terms of endothelial dysfunction and increased risks of atherosclerotic disease including hypertension, dyslipidemia, diabetes mellitus, aging and coronary heart disease ${ }^{(8)}$. Many diseases such as hypercholesterolemia, hypertension, diabetes, cardiovascular disease, and insulin resistance have been noted to be correlated with increased levels of ADMA. Our results were in line with those found by Rossenbach et al, who reported a decrease in ADMA levels $(-74.1 \pm 23 \%)$ via LDL-apheresis ${ }^{(15)}$. We found significantly lower ADMA levels in post-LDLapheresis homozygous patients when compared with heterozygous hyperlipidemic patients and healthy subjects.

P-selectin is a considerably interesting factor, because it is expressed, under defined conditions, by both platelets and endothelial cells. P-selectin expression on activated platelets seems not only a significant factor to facilitate leukocyte and/or endothelial adhesion; moreover, it is important for inter-platelet aggregation, stabilizing the initial gpIIb/IIIafibrinogen interactions, thus allowing the formation of large and stable platelet aggregates. Additionally, p-selectin may support the process of adhesion of platelets and neutrophils to the endothelium, and it is considered to be responsible for further activation of endothelium. P-selectin has additional procoagulant activities, as regulating the production of platelet activating factor by monocytes and priming monocytes against increased phagocytosis, as well as inducing the formation of tissue factor thus possibly having a role in inflammation and atherogenesis ${ }^{(16)}$.

In the present study we demonstrate higher levels of p-selectin in heterozygous group when compared 
with the post-apheresis homozygous group and the control group. However, the demonstrated difference was not statistically significant. These findings were correlated with the outcomes of the report by Stefanutti et al, demonstrating a statistically insignificant reduction in p-selectin via LDL-apheresis ${ }^{(17)}$. Moreover, it has been reported that some medical treatments such as ACE inhibitors, calcium channel blockers, and statins may decrease p-selectin levels ${ }^{(18)}$. All our patients were on statin treatment, which may be another reason for low p-selectin documented in our study.

Nitrotyrosine is formed by peroxynitrite (ONOO-) mediated nitration of tyrosine or in the presence of active metabolite NO in combination with other radicals, and it has been identified in recent years as a useful marker for inflammation and NO mediated tissue injury ${ }^{(19,20)}$. The presence of peroxynitritederived nitrotyrosines in atherosclerotic lesions has been demonstrated in rabbit models ${ }^{(21)}$. Nitrotyrosine levels were insignificantly elevated in the heterozygous FH group, compared with the control group. High nitrotyrosine levels of the heterozygous patient group, even if interpreted as nonsignificant, might support the findings that early atherosclerosis may develop in dyslipidemic patients, which is supposed to be more valuable when examined in larger patient population. Nitrotyrosine levels in the homozygous FH group at post-LDL-apheresis status were below the detection limit of the method. Therefore, our study has demonstrated the ability of LDL-apheresis to reduce nitrotyrosine levels immediately following treatment. On the other hand, a numeric value for nitrotyrosine was not given, except one patient's data included in the statistical analysis.

In dyslipidemic children, lipid deposition in the intima-media layers of arteries may form fatty streaks in early stages, leading to atherosclerosis later in life, which is considered as the pioneer of neurological and cardiovascular diseases in the elderly ages. Early atherosclerotic lesions in surviving patients can be localized through non-invasive ultrasonographic measurement of the arterial intima-media thickness. This method has been quite widely used especially in the diagnosis of the children aged between 11-17 years, and increased CIMT is considered as an important indicator for the risk assessment of stroke, perip- heral vascular diseases, and fatal diseases such as myocardial infarction. We detected positive correlation between CIMT and homocysteine levels in accordance with other studies ${ }^{(22,23)}$. This finding is supporting the risk of progression to atherosclerosis in children with dyslipidemia.

Although the basic approach in the treatment of hyperlipidemia is recognized as dietary adjustments and life style modifications, the influence of this approach may sometimes remain limited, and the desired blood lipid levels may not be achieved. Therefore, lipid-lowering drugs and other treatment options have been referenced. For the cases with homozygous familial hypercholesterolemia demonstrating limited or no response to drug therapy, LDL-apheresis is the classical therapy model ${ }^{(24)}$.

Our study has several limitations. The preLDL-apheresis levels of all investigated parameters would have been desirable for homozygous patients. The patients did not undergo cardiac evaluation immediately after LDL-apheresis procedure. Furthermore, alternative parameters such as tissue factor, tissue factor pathway inhibitor, plasminogen activator inhibitor and von Willebrand Factor could have been used for the evaluation of endothelial function.

In reviewing literature, there are data concerning lipid apheresis causing a significant decrease in the circulating hs-CRP, homocysteine and some adhesion molecules in studies conducted with adults (17); however, we couldn't find any report about effects of LDL apheresis therapy on ADMA, homocysteine, nitrotyrosine and p-selectin levels in hypercholesterolemic children. In this respect, our study is important as being the first study on this issue conducted with children. The main result of presented study is that ADMA and homocysteine levels decreased with LDL apheresis therapy, while p-selectin remained unchanged.

\section{CONCLUSION}

Our data showed that at post-LDL apheresis status the homozygous hyperlipidemic children have lower levels of homocysteine, ADMA, and nitrotyrosine, compared with the heterozygous hyperlipidemic children. So it can be suggested that the 
down-regulatory effect of LDL-apheresis on markers of endothelial function is a rather direct effect of LDL-apheresis procedure than indirect mechanism related to reduced LDL-cholesterol. Further studies including long-term follow-up in a larger patient groups are needed to establish the effect of LDL-apheresis on the vascular bed in homozygous FH patients.

\section{REFERENCES}

1. Raal FJ, Santos RD. Homozygous familial hypercholesterolemia: Current perspectives on diagnosis and treatment. Atherosclerosis 2012;223(2):262-8.

http://dx.doi.org/10.1016/j.atherosclerosis .2012.02.019

2. Libby P, Ridker PM, Maseri A. Inflammation and atherosclerosis. Circulation 2002;105:1153-1143. http://dx.doi.org/10.1161/hc0902.104353

3. Davignon J, Ganz P. Role of endothelial dysfunction in atherosclerosis. Circulation 2004;15;109(23 Suppl 1):III27-32.

4. Ferroni P, Basili S, Davi G. Platelet activation, inflammatory mediators and hypercholesterolemia. Curr Vasc Pharmacol 2003;1(2):157-69. http://dx.doi.org/10.2174/1570161033476772

5. Bröijersén A, Karpe F, Hamsten A, Goodall AH, Hjemdahl P. Alimentary lipemia enhances the membrane expression of platelet P-selectin without affecting other markers of platelet activation. Atherosclerosis 1998;137(1):107-13. http://dx.doi.org/10.1016/S0021-9150(97)00260-8

6. Nygard O, Nordrehaug JE, Refsum H, Ueland PM, Farstad $\mathrm{M}$, Vollset SE. Plasma Homocysteine Levels and Mortality in Patients with Coronary Artery Disease. N Engl J Med 1997;337:230-237. http://dx.doi.org/10.1056/NEJM199707243370403

7. Clarke R, Daly L, Robinson K, Naughten E, Cahalane S, Fowler $\mathrm{B}$, et al. Hyperhomocysteinemia: an independent risk factor for vascular disease. $N$ Engl J Med 1991;25;324(17):1149-55.

8. Schnabel R, Blankenberg S, Lubos E, Lackner KJ, Rupprecht $\mathrm{HJ}$, Espinola-Klein C, et al. Asymmetric dimethylarginine and the risk of cardiovascular events and death in patients with coronary artery disease: results from the AtheroGene Study. Circ Res 2005;97:53-9.

http://dx.doi.org/10.1161/01.RES.0000181286.44222.61

9. Beckman JS and Koppenol WH. NO, superoxide and peroxynitrite: the good, the bad, the ugly. Am J Physiol 1996;271:1424-1437.

10. Coker M, Ucar SK., Simsek DG, Darcan S, Bak M, Can S. Low density Lipoprotein apheresis in pediatric patients with homozygous familial hypercholesterolemia. Therapeutic Apheresis and Dialysis 2009;13(2):121-12. http://dx.doi.org/10.1111/j.1744-9987.2009.00666.x

11. Zöllner N, Kirsch K. Uber die quantitative Bestimmung von Lipoiden (Mikromethode) mittels der vielen natu"rlichen Lipoiden (allen bekannten Plasmalipoiden) gemeinsamen
Sulfophosphovanillin-Reaktion. Z Ges Exp Med 1962; 135:545-561.

http://dx.doi.org/10.1007/BF02045455

12. Moriarty PM, Gibson CA. Low-Density Lipoprotein Apheresis in the Treatment of Atherosclerosis and Other Potential Uses. Current Atherosclerosis Reports 2001;3:156-162. http://dx.doi.org/10.1007/s11883-001-0052-5

13. McCully KS. Homocysteine and vascular disease. Nat Med 1996;2:386-389. http://dx.doi.org/10.1038/nm0496-386

14. Hovland A, Hardersen R, Nielsen EW, Mollnes TE, Lappegård KT. Hematologic and hemostatic changes induced by different columns during LDL apheresis. J Clin Apher 2010;25(5):294-300 . http://dx.doi.org/10.1002/jca.20256

15. Rossenbach J, Mueller GA, Lange K, Armstrong VW, Schmitto JD, Hintze E, et al. Lipid-apheresis improves microcirculation of the upper limbs. J Clin Apher 2011;26(4):167-73. http://dx.doi.org/10.1002/jca.20285

16. Blann AD, Nadar SK, Gregory YH. Lip. The adhesion molecule P-selectin and cardiovascular disease. European Heart Journal 2003;24:2166-2179. http://dx.doi.org/10.1016/j.ehj.2003.08.021

17. Stefanutti C, Vivenzio A, Di Giacomo S, Ferraro PM. Cytokines profile in serum of homozygous familial hypercholesterolemia is changed by LDL-apheresis. Cytokine 2011;55(2):245-50. http://dx.doi.org/10.1016/j.cyto.2011.04.003

18. Bröijersén A, Karpe F, Hamsten A, Goodall AH, Hjemdahl P. Alimentary lipemia enhances the membrane expression of platelet P-selectin without affecting other markers of platelet activation. Atherosclerosis 1998;137(1):107-13. http://dx.doi.org/10.1016/S0021-9150(97)00260-8

19. Beckman JS, Ye YZ, Anderson PG. Extensive nitration of protein tyrosines in human atherosclerosis detected by immunohistochemistry. Biol Chem Hoppe-Seyler 1994;375:81-88. http://dx.doi.org/10.1515/bchm3.1994.375.2.81

20. Beckman JS, Koppenol WH, Nitric oxide, superoxide, and peroxynitrite: The good, the bad, and the ugly. Am J Physiol 1996;271:1424-1437.

21. Hayashi T, Rani P JA, Fukatsu A, Matsui-Hirai H, Osawa M, Miyazaki A, et al. A new HMG-CoA reductase inhibitor, pitavastatin remarkably retards the progression of high cholesterol induced atherosclerosis in rabbits. Atherosclerosis 2004;176(2):255-263.

22. Baptista AP, Cacdocar S, Palmeiro H, Faísca M, Carrasqueira $\mathrm{H}$, Morgado E, et al. Inflammation, homocysteine and carotid intima-media thickness. Rev Port Cardiol 2008;27(1):39-48.

23. Durga J, Verhoef P, Bots ML, Schouten E. Homocysteine and carotid intima-media thickness:a critical appraisal of the evidence. Atherosclerosis 2004;176(1):1-19. http://dx.doi.org/10.1016/j.atherosclerosis.2003.11.022

24. Thompson GR, Catapano A, Saheb S, Atassi-Dumont M, Barbir M, Eriksson M, et al. Severe hypercholesterolaemia: therapeutic goals and eligibility criteria for LDL apheresis in Europe. Curr Opin Lipidol 2010;21(6):492-8. http://dx.doi.org/10.1097/MOL.0b013e3283402f53 